\title{
Preliminary Study on the Bacterial Community Structure of Ganoderma Soil Under Oil Palm Plantation
}

\author{
F Hidayat ${ }^{1}{ }^{1 *}$, R Farrasati $^{1}$, I Pradiko ${ }^{1}$, E Listia $^{1}, \mathrm{M} \mathrm{Syarovy}^{1}, \mathrm{~S} \mathrm{Rahutomo}^{1}$ and \\ Winarna
}

\author{
${ }^{1}$ Indonesian Oil Palm Research Institute Jl. Brigjen Katamso No. 51 Kampung Baru, Medan, North Sumatera, \\ Indonesia 20158 \\ *Corresponding author. Email: fandi.hidayat87@gmail.com
}

\begin{abstract}
Basal stem rot (BSR) disease is caused by Ganoderma boninense; it has become a major disease in oil palm plantations over the years and causes a significant yield drop in oil palm plantations, especially in Sumatera. Nowadays, the incidence level of BSR across Sumatera has reached $39 \%$ and is predicted to keep increasing and threatening the sustainability of oil palm plantations between 2050 and 2100. Some researchers believe that Ganoderma is dominant due to the unbalance of the microbial community in the soil ecosystem. This study aims to discover the bacterial community structure in the soil under Ganoderma boninense infection in oil palm plantations. The study was conducted by comparing the soil infected by Ganoderma boninense (G+) and the healthy soil (G-) through the next-generation sequencing (NGS) by Illumina MiSeq. The study shows that the total bacteria of the healthy soil (G-) was 177 times higher than the endemic soil with a total copy number $1.32 \times 10^{8}$ and $7.44 \times 10^{5}$, respectively. Acidobacteria was the dominant phyla in the healthy soil (G-), followed by Proteobacteria, and their relative abundance are $31.45 \%$ and $29.19 \%$, respectively. On the other hand, the relative abundance of Acidobacteria in the endemic soil (G+) was decreased to $18.73 \%$ while Proteobacteria was increased to $38.34 \%$. However, the abundance of these phyla in the endemic soil $(\mathrm{G}+)$ is still lower than in the healthy soil (G-). At the level species, the healthy soil (G-) was more diverse than the endemic soil (G+). It shows that the endemic soil is more susceptible to Ganoderma boninense due to its dominance in the soil ecosystems. The 16S rRNA gene sequencing revealed that more than $60 \%$ of OTUs had $<98 \%$ of similarity. It is indicated that some species, both in healthy soil (G-) and endemic soil $(\mathrm{G}+)$, under oil palm plantations might be novel species.
\end{abstract}

Keywords: Bacterial community structure, Ganoderma, Next generation sequencing, Oil palm.

\section{INTRODUCTION}

The oil palm plantations have increased rapidly as it's the biggest contributors to Indonesia's foreign exchange, reduced poverty, and improved livelihoods $[1,2,3]$. At present, over 14 million hectares of oil palm plantations have been cultivated by the government (5\%), private companies (54\%), and smallholders (41\%) [4]. Nevertheless, the achievement of production tends to decline due to various factors, such as diseases.
Basal stem rot (BSR) disease reported as the major disease in oil palm plantations is caused by the white-rot fungus Ganoderma boninense and is responsible for 50 to $80 \%$ yield losses by decreasing the yield density [5]. The incidence of BSR continues to increase. It has been predicted that the disease will affect the oil palm sustainability during 2050-2100 [6]. This fungus preferentially degrades the lignin component of wood tissues and lives as the saprophytic in a natural ecosystem [7]. The disease was first discovered in West Africa in 1915 and found on 25-year-old oil palms in 
1931 [8]. The primary route of infection appears to be through root contact with the inoculum in the soil [9].

On the other hand, other microorganisms, such as bacteria, are important in the soils as carbon cycler via fixation and decomposition. Some bacteria are important decomposers and their communities' structure is affected by soil management, and, hence, can shift the dominance of decomposers from bacterial to fungal. Once it occurs in the soil ecosystems, some researchers believe that Ganoderma could be dominant and

negatively impacts plant growth and productivity. Therefore, this study was conducted to obtain a comparison of the bacterial community structures between healthy soils and infected soils under the oil palm plantations.

\section{METHODOLOGY}

Two soil samples, (i) healthy soil (G-) and (ii) endemic soil $(\mathrm{G}+)$, were collected from the oil palm plantation in Aek Pancur Station, Tanjung Morawa, North Sumatera in 2016. MiSeq analysis was performed to compare the bacterial community among the samples through several steps analyses, which is described in the flowchart below (Figure 1).

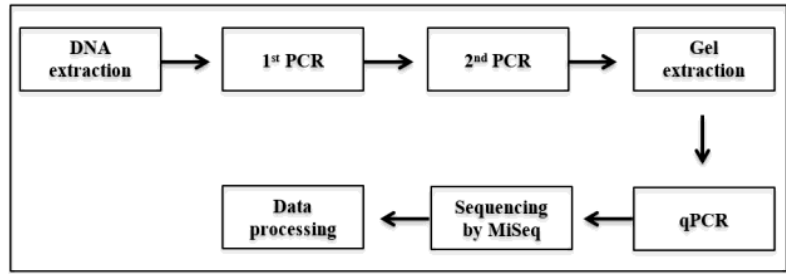

Figure 1. Flowchart of the MiSeq analysis

DNA extraction. DNA was extracted from the soil samples using the PowerSoil ${ }^{\circledR}$ DNA Isolation Kit (Mo Bio Laboratories, Inc., Carlsbad, CA, USA) according to the manufacturer's instructions (Mo Bio Laboratories, Inc.). The DNA concentration was then measured by Thermo Scientific ${ }^{\mathrm{TM}}$ NanoDrop 2000 Spectrophotometer (Thermo Fisher Scientific Inc., Waltham, MA, USA). The DNA was then amplified by a two-stage PCR $\left(1^{\text {st }}\right.$ stage PCR and $2^{\text {nd }}$ stage PCR) before next-generation sequencing (NGS) using the Illumina MiSeq Sequencing Platform.

$\boldsymbol{I}^{\text {st }}$ stage PCR. The primers set
(GTGCCAGCMGCCGCGGTAA) and $806 \mathrm{~F}$
(GGACTACHVGGGTWTCTAAT) were used and
initially heat-shocked at $95^{\circ} \mathrm{C}$ for 5 minutes. For the first
stage PCR, $12.5 \mathrm{ng}$ of DNA templates, $1 \mu$ of each
primer $(5 \mu \mathrm{M}), 12.5 \mu \mathrm{l}$ of Kapa HiFi HotStart Ready
Mix, and up to $25 \mu \mathrm{l}$ of sterilized ultrapure water were
utilized. Amplification was then performed as follows:
(1) initial denaturation at $95^{\circ} \mathrm{C}$ for 3 minutes, (2) 25
cycles of denaturation at $98^{\circ} \mathrm{C}$ for 30 seconds, (3)

annealing at $55^{\circ} \mathrm{C}$ for 30 seconds, (4) elongation at $72^{\circ} \mathrm{C}$ for 30 seconds, and (5) a final extension at $72^{\circ} \mathrm{C}$ for 5 minutes. The PCR was performed using the TaKaRa thermal cycler and repeated twice for each sample. To confirm the amplification of PCR products, electrophoresis using 1.5\% agarose gel was performed for 30 minutes. After electrophoresis, the gel was immersed in $\mathrm{EtBr}$ solution for 20 minutes and was observed under the UV light (Bio-Rad Laboratories, Inc., Hercules, CA, USA). The PCR products were then purified using FastGene ${ }^{\mathrm{TM}}$ PCR Extraction Kit (Nippon Genetics Co., Ltd.). After the purification, the concentration of DNA was measured using Thermo Scientific $^{\mathrm{TM}}$ NanoDrop 2000 Spectrophotometer (Thermo Fisher Scientific Inc., Waltham, MA, USA).

$2^{\text {nd }}$ PCR and Gel extraction. For the second stage $\mathrm{PCR}$, different index forward and reverse primer set (2F-5XX and 2R-7XX) were used for each sample with the primer set, as showed in Table 1 . The $40 \mathrm{ng}$ of DNA template (1st PCR product's) was mixed with $0.5 \mu \mathrm{l}$ of each index primer $(10 \mu \mathrm{M}), 12.5 \mu \mathrm{l}$ of Kapa $\mathrm{HiFi}$ HotStart Ready Mix, and adjusted up to volume $25 \mu \mathrm{l}$ with sterilized ultrapure water. Amplification was then performed as follows: (1) initial denaturation at $95^{\circ} \mathrm{C}$ for 3 minutes, (2) 8 cycles of denaturation at $98^{\circ} \mathrm{C}$ for 30 seconds, (3) annealing at $55^{\circ} \mathrm{C}$ for 30 seconds, (4) elongation at $72^{\circ} \mathrm{C}$ for 30 seconds, and (5) final extension at $72^{\circ} \mathrm{C}$ for 5 minutes. as Additionally, as in the first stage PCR, the amplification also performed using the TaKaRa thermal cycler. All PCR products were then electrophoresis using $1.5 \%$ of agarose gel for 30 minutes in $100 \mathrm{~V}$, to confirm the amplification of PCR products. After electrophoresis, the gel was immersed in a fresh EtBr solution for 20 minutes and was observed under UV light (Bio-Rad Laboratories, Inc., Hercules, CA, USA). Gel extraction was then performed using the FastGene ${ }^{\mathrm{TM}}$ Gel Extraction Kit (Nippon Genetics Co., Ltd.) to purify the PCR products. The DNA concentration was then measured by the Qubit $^{\circledR}$ 3.0 Fluorometer (Thermo Fisher Scientific, Waltham, MA, USA).

Table 1. The index primer set for each sample in the second stage PCR

\begin{tabular}{cccc}
\hline No & Sample & F-Primer & R-Primer \\
\hline 1 & G- & 2F-501 & 2R-709 \\
& & (TAGATCGC) & (AGCGTAGC) \\
2 & G+ & 2F-501 & 2R-710 \\
& & (TAGATCGC) & (CAGCCTCG) \\
\hline
\end{tabular}

$\boldsymbol{q P C R}$. The quantification of cell (copy number) in DNA from each sample was conducted by real-time qPCR using a primer $357 \mathrm{~F}$ (CCTACGGGAGGCAGCAG) and 518R (ATTACCGCGGCTGCTGG). One $\mu \mathrm{l}$ of the crude 
DNA (from DNA extraction) was mixed with $0.1 \mu 1$ of each primer (10 pmol), $5 \mu \mathrm{l}$ of KOD SYBR Mix, and $3.8 \mu \mathrm{l}$ of sterilized ultra-pure water. One negative control and seven serial dilutions of E. coli $\left(10^{-1}\right.$ to $\left.10^{-7}\right)$ were used as a template for the standard. The PCR condition was as follows: (1) initial denaturation at $95^{\circ} \mathrm{C}$ for 5 minutes, (2) 40 cycles of denaturation at $95^{\circ} \mathrm{C}$ for 5 seconds, (3) annealing at $64^{\circ} \mathrm{C}$ for 20 seconds, and (4) elongation at $72^{\circ} \mathrm{C}$ for 20 seconds. The real-time qPCR was conducted using the CFX Connect ${ }^{\mathrm{TM}}$ Real-Time PCR Detection System (Bio-Rad Laboratories, Inc., Hercules, CA, USA). The total cell (copy number. $g^{-1}$ ) of the samples was calculated by using the equation below:

Total cell $=S Q \times \frac{1}{S W} \times \frac{100}{D V}$

SQ $\quad$ : detected copy number from $1 \mu 1$ sample

SW : sample weight for DNA extraction $(0.25 \mathrm{~g})$

DV : elution volume of DNA extraction $(100 \mu \mathrm{l})$

MiSeq analysis and Data processing. A DNA library (a mixture of PCR amplicons) was prepared at 4 $\mathrm{nM}$ concentration. The Illumina MiSeq Sequencing Platform (Illumina, San Diego, CA, USA) [10] was then run for 60 hours. Finally, bioinformatics and phylogenetic analyses were performed using USEARCH and QIIME pipelines [11, 12, 13].

\section{RESULT AND DISCUSSION}

\subsection{Sequencing statistic of the MiSeq results}

After sequencing the V3-V4 region, total 11,952 raw reads were obtained from all samples via barcoded pyrosequencing. As shown in Table 2, after filtering the low quality reads using the QIIME standard pipeline, a total of 2,388 - 3,056 (43.2 - 49.0\%) high-quality clean reads were obtained from all the samples. The alpha rarefaction resulted in the relatively good coverage in all samples, i.e., >0.9 at 2,000 sequences. It was indicated that the MiSeq result is reliable.

Table 2. The number of reads, total OTU, and relative coverage after filtration

\begin{tabular}{cccccc}
\hline Sample & $\begin{array}{c}\text { Raw } \\
\text { reads }\end{array}$ & $\begin{array}{c}\text { Filtered } \\
\text { reads }\end{array}$ & $\boldsymbol{\%}^{\boldsymbol{a}}$ & $\begin{array}{c}\text { Total } \\
\text { OTU }\end{array}$ & $\begin{array}{c}\text { Relative } \\
\text { good } \\
\text { coverage }\end{array}$ \\
\hline G- & 7080 & 3056 & 43.2 & 296 & 0.906 \\
G+ & 4872 & 2388 & 49.0 & 227 & 0.904 \\
\hline a \% of final read: Filtered Reads / Raw Reads \\
\hline
\end{tabular}

\subsection{Total cell and the bacterial diversity}

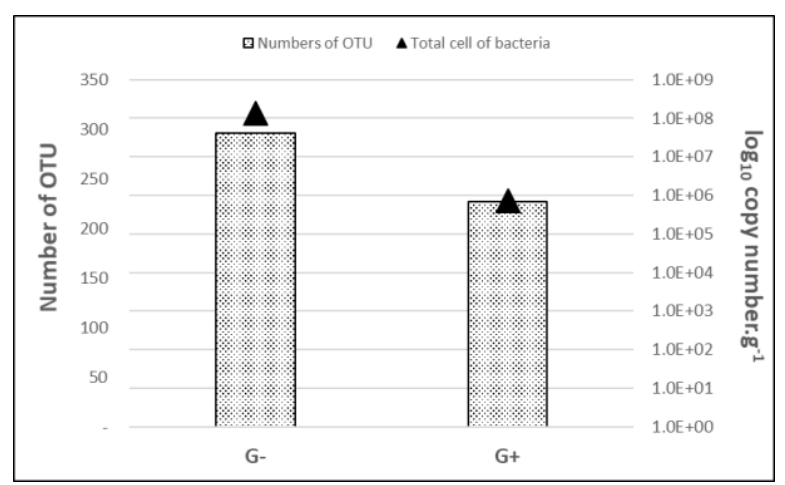

Figure 2. Comparison of total cell and the bacterial diversity between the healthy soil (G-) and endemic soil $(\mathrm{G}+)$

Figure 2 shows the comparison of the total cell and number of OTUs between the healthy soil (G-) and endemic soil $(\mathrm{G}+)$. In total, the bacteria cell of healthy soil (G-) as 177 times higher than the endemic soil $(\mathrm{G}+)$ with the copy number as $1.32 \times 10^{8}$ and $7.44 \times 10^{5}$, respectively. Furthermore, the number of OTU was also higher in the healthy soil (296 OTUs) than in the endemic soil (227 OTUs). It is indicated that endemic soil $(\mathrm{G}+)$ has less cell number and less diversity in the bacterial community. Consequently, the chance of Ganoderma developing and becoming a dominant organism in the soil ecosystem is much stronger.

\subsection{Bacterial community structure}

Figure 3 shows the bacterial community structure at the phylum level. Three major bacterial phyla that represented $>1 \%$ of each community composition were present in an all samples, namely-Acidobacteria (18.7 - 31.4\%), Actinobacteria (10.7 - 24.9\%), and Proteobacteria $(29.2-38.3 \%)$. Our findings are in line with the study on the bacterial biodiversity in oil palm plantations at Sarawak, Malaysia. The latter study also found that Acidobacteria, Actinobacteria, and Proteobacteria were the most prevalent phyla [14]. In healthy soil, the relative abundance of Acidobacteria was the highest at $31.45 \%$, followed by Proteobacteria at $29.19 \%$ with respect to total bacteria. Conversely, Proteobacteria was the dominant phylum in endemic soil (G+) with the relative abundance of about $38.34 \%$, while Acidobacteria was decreased to $18.73 \%$. However, according to the copy number of the major phyla (Figure 4), the occurrence of Acidobacteria, Actinobacteria, and Proteobacteria in endemic soil $(\mathrm{G}+)$ is lower than that in healthy soil (G-). It is indicated that the endemic soil is more susceptible to Ganoderma boninense. It is supported by another study that stated that Ganoderma boninense was elevated with a decline in the presence of indigenous beneficial bacteria [15]. In general, the changes in bacterial composition are more influenced by the agricultural 
activities that lead to the reduction of biodiversity and abundance $[14,16]$.

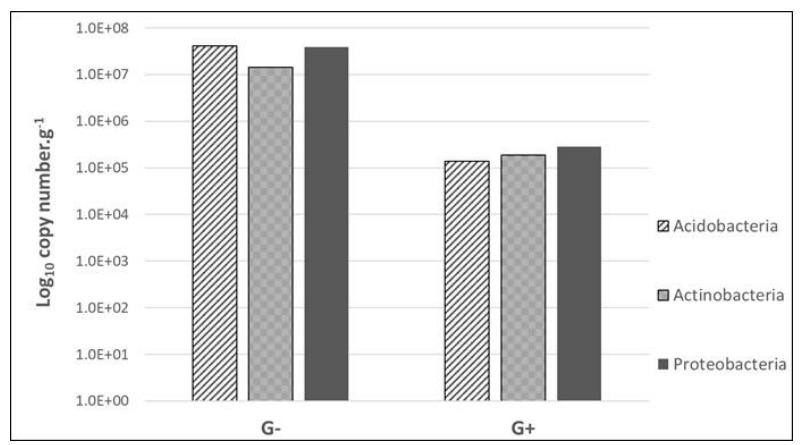

Figure 3. The relative abundance of the phylum level between healthy soil (G-) and endemic soil $(\mathrm{G}+)$

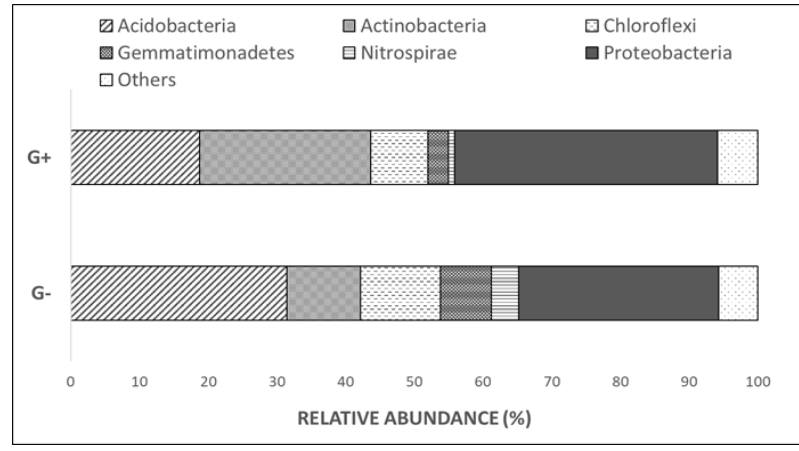

Figure 4. Comparison of the copy number among the major phyla in healthy soil (G-) and endemic soil $\left(\mathrm{G}^{+}\right)$

Table 3. The occurrence of OTUs in healthy soil (G-) and endemic soil (G+) at $1 \%$ cutoff

\begin{tabular}{|c|c|c|c|c|c|}
\hline OTU ID & G- & G+ & Related species & Similarity (\%) & Phylum \\
\hline Otu225 & 1.32 & 4.22 & Chujaibacter soli & 100 & Proteobacteria \\
\hline Otu346 & 0.93 & 1.36 & Actinoplanes lichenis & 99 & Actinobacteria \\
\hline Otu135 & 0.22 & 1.24 & Bradyrhizobium oligotrophicum & 99 & Proteobacteria \\
\hline Otu217 & 0.60 & 2.11 & Pseudomonas oleovorans & 99 & Proteobacteria \\
\hline Otu238 & 2.14 & - & Sphingomonas limnosediminicola & 99 & Proteobacteria \\
\hline Otu727 & 0.93 & 1.12 & Blastochloris viridis & 96 & Proteobacteria \\
\hline Otu395 & 3.13 & 0.75 & Luteitalea pratensis & 95 & Acid obacteria \\
\hline Otu142 & 0.27 & 6.70 & Actinomadura umbrina & 95 & Actinobacteria \\
\hline Otu62 & 0.55 & 1.36 & Gaiella occulta & 94 & Actinobacteria \\
\hline Otu123 & 1.54 & 0.74 & Sulfuritortus calidifontis & 94 & Proteobacteria \\
\hline Otu276 & 1.87 & - & Brevitalea aridisoli & 94 & Acid obacteria \\
\hline Otu524 & 0.44 & 2.61 & Aliidongia dinghuensis & 93 & Proteobacteria \\
\hline Otu539 & 4.56 & 1.49 & Vicinamibacter silvestris & 93 & Acid obacteria \\
\hline Otu191 & 2.14 & 2.36 & Denitratisoma oestradiolicum & 92 & Proteobacteria \\
\hline Otu417 & 1.59 & - & Skermanella rubra & 92 & Proteobacteria \\
\hline Otu246 & 0.55 & 1.36 & Azospirillum brasilense & 92 & Proteobacteria \\
\hline Otu279 & 1.15 & - & Gemmatimonas aurantiaca & 92 & Gemmatimonadetes \\
\hline Otu370 & 1.75 & 2.23 & Acidobacterium ailaaui & 91 & Acid obacteria \\
\hline Otu700 & 1.04 & 1.12 & Paludibaculum fermentans & 90 & Acid obacteria \\
\hline Otu187 & 0.60 & 1.12 & Gemmatimonas phototrophica & 90 & Gemmatimonadetes \\
\hline Otu139 & 3.52 & 0.12 & Gemmatimonas aurantiaca & 89 & Gemmatimonadetes \\
\hline Otu206 & 0.38 & 2.61 & Kushneria pakistanensis & 89 & Proteobacteria \\
\hline Otu394 & 1.15 & 0.25 & Desulfonatronum thioautotrophicum & 88 & Proteobacteria \\
\hline Otu281 & 0.77 & 1.49 & Granulicella acidiphila & 86 & Acid obacteria \\
\hline Otu529 & 1.04 & 0.37 & Actinomadura atramentaria & 85 & Actinobacteria \\
\hline Otu353 & 1.21 & - & Thermaerobacter composti & 83 & Firmicutes \\
\hline Otu216 & 2.14 & - & Ktedonobacter racemifer & 83 & Chloroflexi \\
\hline Otu168 & 0.16 & 2.73 & Ktedonobacter racemifer & 82 & Chloroflexi \\
\hline
\end{tabular}


An OTU table representing the occurrence of each OTU in each sample was utilized to make a heat map. Following the quality filter, a total of 28 OTU groups with a dominant $1 \%$ or more were only considered. Each OTU was compared with previously identified species in the NCBI Database, as presented in Table 3. Among the selected OTU's, only four OTUs from Proteobacteria and one OTU from Actinobacteria had $>99 \%$ similarity, while the rest showed less than $98 \%$ similarity. This study suggests that mostly OTUs are likely unclassified and might be novel species. This finding allows an opportunity to further study the characterization of species under the oil palm plantations. The OTU's heatmap table shows that at least ten OTUs of healthy soil (G-) has substantial differences in the occurrence percentage with endemic soil (G+), namely-OTU 238, OTU 395, OTU 276, OTU 539, OTU 417, OTU 279, OTU 139, OTU 394, OTU 353, and OTU 216. Yet, the presence of all species in healthy soil is still higher than that in endemic soil.

\section{CONCLUSION}

The results of the MiSeq analysis show that three major phyla were found both in healthy soil and soil infected by Ganoderma boninense, namelyAcidobacteria, Actinobacteria, and Proteobacteria. The total cell number in healthy soil was greater than that in endemic soil. Consequently, the soil pathogen Ganoderma boninense in endemic soil was elevated during the reduction of beneficial bacteria, which then drives the Ganoderma in becoming dominant in the soil ecosystem.

\section{REFERENCES}

[1] Budidarsono S, Rahmanulloh A, and Sofiyuddin M 2012 Technical Brief 26: Palm Oil Series

[2] Edwards R 2015 Job Market Paper Canberra, Australia

[3] Lee JSH, Ghazoul J, Obidzinki K, and Koh LP 2013 Agronomy for Sustainable Development 34 501-513

Directorate General of Estate Crops 2017 Tree Crop Estate Statistics of Indonesia 2016-2018 (Jakarta: Secretariate of Directorate General of Estate Crops) p 55

[4] Corley RHV and Tinker PB 2016 The Oil Palm $5^{\text {th }}$ Ed. (Hoboken: Willey and Black)

[5] Paterson RRM 2019 Moicroorganisms 7

[6] Thomas WC, Boddy L, and Jones TH 2012 The ISME Journal 6 1992-2001

[7] Naher L, Yusuf UK, Tan SG, and Ismail I 2013 Australian Journal of Crop Science 7 1723-1727

[8] Rees RW, Flood J, Hasan Y, Potter U, and Copper RM 2009 Plant Pathology 58 982-989

[9] Caporaso JG, Lauber CL, Walters WA, Lyons DB, Huntley J, Fierer N, Owens SM, Betley J, Fraser L, Bauer M, Gormley N, Gilbert JA,
Smith G, and Knight R 2012 The ISME Journal 6 1621-1624

[10] Edgar RC 2010 Bioinformatics 26 2460-2461

[11] Kuczynski J, Stombaugh J, Walters WA, Gonzales A, Caporaso JG, and Knight R 2011 Microbiology Chapter 10

[12] Bienes KM, Ito M, Shiotsuka K, Yamaguchi S, Fujioka T, Tashiro Y, and Sakai K 2017 J. Biosci. Bioeng. 17

[13] Shamsilawani AB, Ramlah SAA, and Maidin MST 2017 Oil Palm Bulletin 74 12-16

[14] Khunaw AR, Othman R, Ali NS, Musa MH, and Rabara FS 2017 International Journal of Plant \& Soil Science 19 1-14

[15] Situmorang EC, Nugroho YA, Prameswara A, Andarini E, Hartono, Setyobudi RH, Mathius NT, and Liwang T 2016 AIP Conference Proceedings 1744 